\title{
Pittosporum lanipetalum
}

\author{
Assessment by: Gemmill, C., Veillon, J.-M., Amice, R., Cazé, H., Dumontet, V., \\ Fleurot, D., Garnier, D., Gâteblé, G. \& Maggia, L.
}

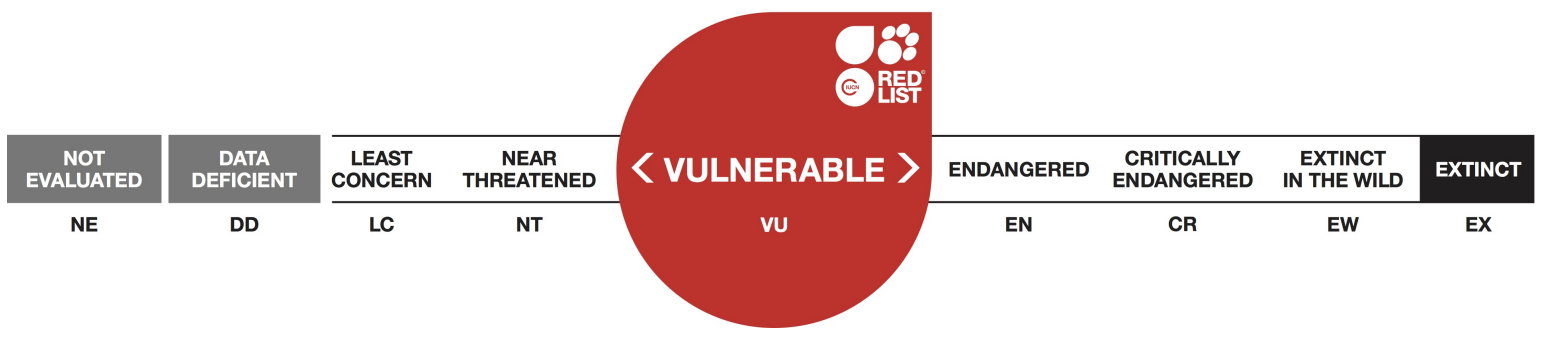

View on www.iucnredlist.org

Citation: Gemmill, C., Veillon, J.-M., Amice, R., Cazé, H., Dumontet, V., Fleurot, D., Garnier, D., Gâteblé, G. \& Maggia, L. 2017. Pittosporum lanipetalum. The IUCN Red List of Threatened Species 2017: e.T82947669A82951822. http://dx.doi.org/10.2305/IUCN.UK.20173.RLTS.T82947669A82951822.en

Copyright: (C) 2017 International Union for Conservation of Nature and Natural Resources

Reproduction of this publication for educational or other non-commercial purposes is authorized without prior written permission from the copyright holder provided the source is fully acknowledged.

Reproduction of this publication for resale, reposting or other commercial purposes is prohibited without prior written permission from the copyright holder. For further details see Terms of Use.

The IUCN Red List of Threatened Species ${ }^{T M}$ is produced and managed by the IUCN Global Species Programme, the IUCN Species Survival Commission (SSC) and The IUCN Red List Partnership. The IUCN Red List Partners are: Arizona State University; BirdLife International; Botanic Gardens Conservation International; Conservation International; NatureServe; Royal Botanic Gardens, Kew; Sapienza University of Rome; Texas A\&M University; and Zoological Society of London. 


\section{Taxonomy}

\begin{tabular}{|c|c|c|c|c|}
\hline Kingdom & Phylum & Class & Order & Family \\
\hline Plantae & Tracheophyta & Magnoliopsida & Rosales & Pittosporaceae \\
\hline
\end{tabular}

Taxon Name: Pittosporum lanipetalum Tirel \& Veillon

\section{Taxonomic Source(s):}

Tirel, Ch. and Veillon, J.-M. 2002. Flore de la Nouvelle-Calédonie, tome 24. Pittosporaceae. Museum d'Histoire Naturelle, Paris.

\section{Assessment Information}

Red List Category \& Criteria: Vulnerable D1 ver 3.1

Year Published: 2017

Date Assessed: July 23, 2015

\section{Justification:}

Pittosporum lanipetalum is a rare endemic shrub known only from Roches de la Ouaïème in New Caledonia. It is found in open shrubland on volcano-sedimentary substrate, its area of occupancy and extent of occurrence are both equal to $8 \mathrm{~km}^{2}$. A fire outbreak could affect individuals present in open vegetation zones but likely would not affect the entire population in a single event. According to several field observations, population size is estimated to be fewer than 1,000 mature individuals. Using criteria D, P. lanipetalum qualifies for listing as Vulnerable (VU) D1.

\section{Geographic Range}

\section{Range Description:}

Pittosporum lanipetalum is a rare endemic shrub known only from Roches de la Ouaïème in New Caledonia.

\section{Country Occurrence:}

Native: New Caledonia 


\section{Distribution Map}

\section{Pittosporum lanipetalum}
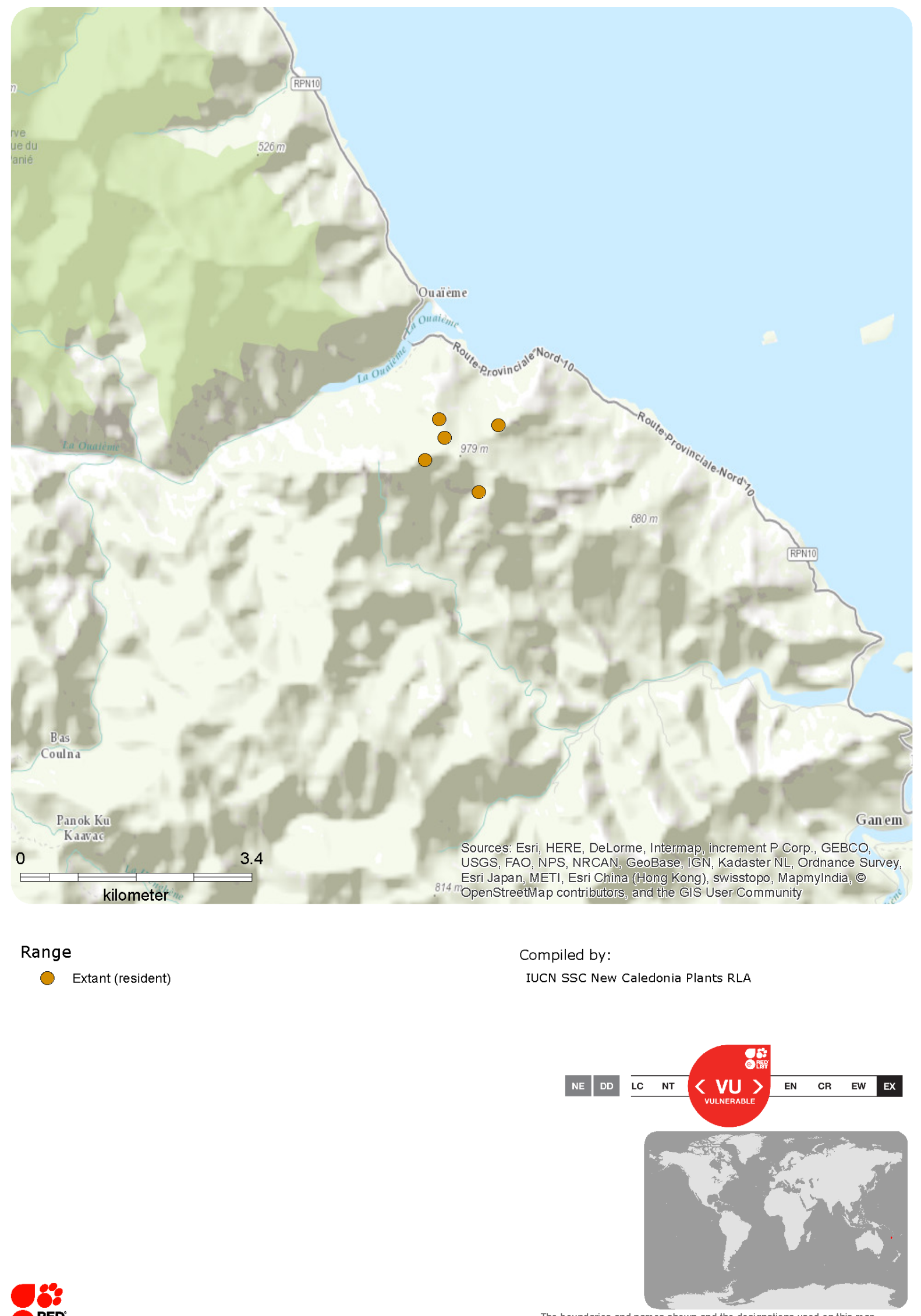


\section{Population}

With only one subpopulation known, population size is estimated to be fewer than 1,000 mature individuals.

Current Population Trend: Stable

\section{Habitat and Ecology (see Appendix for additional information)}

Pittosporum lanipetalum is a species of open shrublands on volcano-sedimentary substrates.

Systems: Terrestrial

\section{Threats (see Appendix for additional information)}

A fire outbreak could affect individuals present in open vegetation zones but likely would not affect the entire population in a single event. Uncontrolled bushfires sweep across New Caledonia each year, especially during the dry season (an average of 20,000 ha of land is burnt each year, with dramatic peaks of 70,000 ha). These fires contribute significantly to habitat fragmentation and hence a dramatic decline in the quality of habitat.

\section{Conservation Actions (see Appendix for additional information)}

Pittosporum lanipetalum is not protected by any legislation nor does it occurs in any protected areas.

\section{Credits}

Assessor(s): $\quad$ Gemmill, C., Veillon, J.-M., Amice, R., Cazé, H., Dumontet, V., Fleurot, D., Garnier, D., Gâteblé, G. \& Maggia, L.

Reviewer(s): $\quad$ Tanguy, V.

Contributor(s): $\quad$ Vandrot, $\mathrm{H}$.

Facilitators(s) and Chanfreau, S.

Compiler(s): 


\section{Bibliography}

Endemia.nc. 2016. Faune et Flore de Nouvelle-Calédonie. Available at: http://www.endemia.nc.

Gomez, C., Mangeas, M., Curt, T., Ibanez, T., Munzinger, J., Dumas, P., Jérémy, A., Despinoy, M. and Hély, C. 2014. Wildfire risk for main vegetation units in a biodiversity hotspot: modeling approach in New Caledonia, South Pacific. Ecology and Evolution 5(2): 377-390. DOI: 10.1002/ece3.1317.

Hély-Alleaume. 2012. INC : Incendies et biodiversité des éco-systèmes en Nouvelle-Calédonie.

IUCN. 2017. The IUCN Red List of Threatened Species. Version 2017-3. Available at: www.iucnredlist.org. (Accessed: 7 December 2017).

Tirel, Ch. and Veillon, J.-M. 2002. Flore de la Nouvelle-Calédonie, tome 24. Pittosporaceae. Museum d'Histoire Naturelle, Paris.

\section{Citation}

Gemmill, C., Veillon, J.-M., Amice, R., Cazé, H., Dumontet, V., Fleurot, D., Garnier, D., Gâteblé, G. \& Maggia, L. 2017. Pittosporum lanipetalum. The IUCN Red List of Threatened Species 2017: e.T82947669A82951822. http://dx.doi.org/10.2305/IUCN.UK.2017-3.RLTS.T82947669A82951822.en

\section{Disclaimer}

To make use of this information, please check the Terms of Use.

\section{External Resources}

For Images and External Links to Additional Information, please see the Red List website. 


\section{Appendix}

\section{Habitats}

(http://www.iucnredlist.org/technical-documents/classification-schemes)

\begin{tabular}{|c|c|c|c|}
\hline Habitat & Season & Suitability & $\begin{array}{l}\text { Major } \\
\text { Importance? }\end{array}$ \\
\hline 3. Shrubland -> 3.5. Shrubland - Subtropical/Tropical Dry & - & Suitable & - \\
\hline
\end{tabular}

\section{Threats}

(http://www.iucnredlist.org/technical-documents/classification-schemes)

\begin{tabular}{|c|c|c|c|c|}
\hline Threat & Timing & Scope & Severity & Impact Score \\
\hline \multirow{2}{*}{$\begin{array}{l}\text { 7. Natural system modifications }->7.1 \text {. Fire \& fire } \\
\text { suppression }->7.1 .1 \text {. Increase in fire } \\
\text { frequency/intensity }\end{array}$} & Ongoing & - & - & - \\
\hline & Stresses: & \multicolumn{3}{|c|}{$\begin{array}{l}\text { 1. Ecosystem stresses } \rightarrow \text { 1.1. Ecosystem conversion } \\
\text { 1. Ecosystem stresses }->1.2 \text {. Ecosystem degradation } \\
\text { 2. Species Stresses }->2.1 \text {. Species mortality }\end{array}$} \\
\hline
\end{tabular}

\section{Conservation Actions in Place}

(http://www.iucnredlist.org/technical-documents/classification-schemes)

\begin{tabular}{|l|}
\hline Conservation Actions in Place \\
\hline In-Place Land/Water Protection and Management \\
\hline Occur in at least one PA: No \\
\hline Invasive species control or prevention: No \\
\hline In-Place Species Management \\
\hline Successfully reintroduced or introduced beningly: No \\
\hline Subject to ex-situ conservation: No \\
\hline
\end{tabular}

\section{Additional Data Fields}

\begin{tabular}{|l|}
\hline Distribution \\
\hline Estimated area of occupancy $(\mathrm{AOO})\left(\mathrm{km}^{2}\right): 8$ \\
\hline Continuing decline in area of occupancy (AOO): No \\
\hline Extreme fluctuations in area of occupancy (AOO): No \\
\hline Estimated extent of occurrence (EOO) $\left(\mathrm{km}^{2}\right): 8$ \\
\hline Continuing decline in extent of occurrence (EOO): No \\
\hline
\end{tabular}




\section{Distribution}

Extreme fluctuations in extent of occurrence (EOO): No

Continuing decline in number of locations: No

Extreme fluctuations in the number of locations: No

Lower elevation limit (m): 600

Upper elevation limit (m): 980

Population

Number of mature individuals: 250-999

Continuing decline of mature individuals: No

Extreme fluctuations: No

Population severely fragmented: No

No. of subpopulations: 1

Extreme fluctuations in subpopulations: No

Habitats and Ecology

Continuing decline in area, extent and/or quality of habitat: No

Generation Length (years): 0 


\section{The IUCN Red List Partnership}

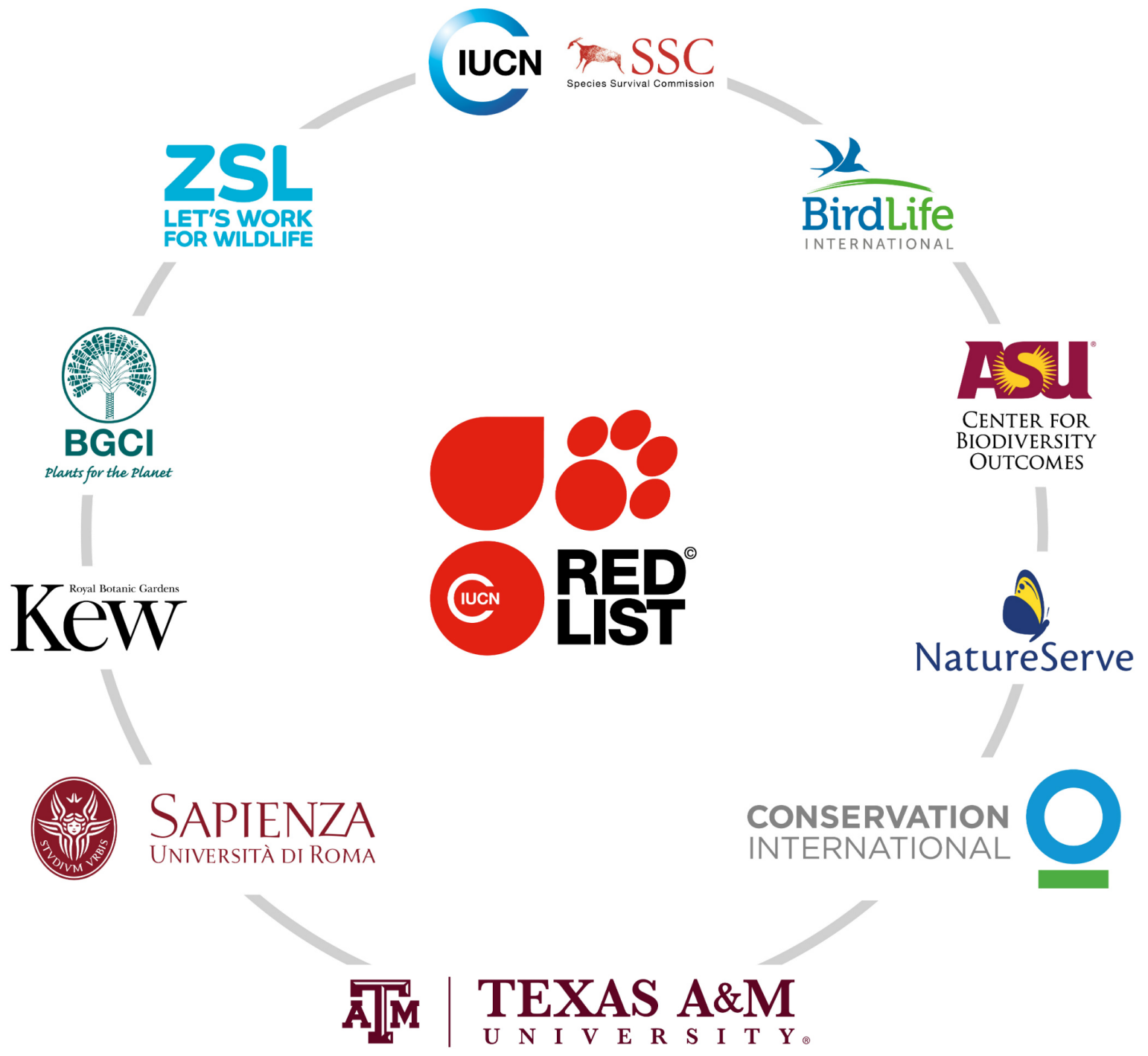

The IUCN Red List of Threatened Species ${ }^{\mathrm{TM}}$ is produced and managed by the IUCN Global Species Programme, the IUCN Species Survival Commission (SSC) and The IUCN Red List Partnership.

The IUCN Red List Partners are: Arizona State University; BirdLife International; Botanic Gardens Conservation International; Conservation International; NatureServe; Royal Botanic Gardens, Kew; Sapienza University of Rome; Texas A\&M University; and Zoological Society of London. 